\title{
Quantitative assessment of sediment transport and channel maintenance capacity of rivers
}

\author{
Robert T Milhous \\ Torries Peak Analysis \\ Fort Collins, Colorado
}

\begin{abstract}
Revised)
Restoration of rivers may require the restoration of streamflows. A quantitative approach to the assessment of the capacity of a river to transport sediment uses a power equation for sediment load in rivers of the form $\mathrm{Sl}=\mathrm{a}$ [Q-Qcrt)**b] $\mathrm{Q}$ as the basis of the assessment process. In the equation $\mathrm{Sl}$ is the sediment load, Q is the discharge, Qcrt is a critical discharge below which the load is zero or only wash load. This equation is used to look at the variation of sediment transport capacity of a river. The equation used to investigate the ability of a river to maintain its channel is $c m c=a\left[Q^{* *} b-Q c r t * b\right]$. In this equation Qcrt is the discharge below which the the channel is not maintained. In both equations the meaning of the Qcrt and $\mathrm{a}$ and $\mathrm{b}$ are different depending on the specific issue being investigated. The second equation is used to look at variation in the ability of the river to maintain its channel. An application of the cmc to the Cache la Poudre (Poudre) River in Colorado used a discharge of $147 \mathrm{~m}^{3} / \mathrm{s}$ as the critical discharge in the cmc equation when the objective is to remove unwanted vegetation from the river channel. The application of the cmc equation showed considerable variation in the ability river to maintain its channel and was reduced as a result of water development. The logic of the index equations used for sediment transport capacity and channel maintenance capacity is explained using data for the Clarks Fork Yellowstone River near Belfry Montana. One approach to evaluating channel maintenance is done using only streamflow information. In this case the channel maintenance capacity is calculated using discharges over a critical discharge determined from an analysis of maximum streamflows. The second used both hydraulic and streamflow information together. The channel maintenance capacity is the shear stress over a critical shear stress.. Both the sediment transport and channel maintenance techniques were used to investigate the impact of a proposed project on the Cache la Poudre River in Colorado.
\end{abstract}

\section{References}

Colorado State Water Engineer. 2016. Cache la Poudre River data downloaded from water data pages.

Anderson Consulting Engineers, Inc. 2013. Stream Morphology and Sediment Transport. Cache la Poudre River Mainsteam Baseline Report in Support of: Northern Integrated Supply Project Supplemental Draft Environmental Impact Statement ; Halligan and Seaman Water Supply Projects Draft Environmental Impact Statement. Prepared for: U.S. Army Corps of Engineers Omaha District. Prepared by: Anderson Consulting Engineers, Inc. 375 E. Horsetooth Road, Bldg. 5. Fort Collins, CO 80525. May 2013. 200 pages.

Milhous, Robert T. 2016. On Quantification of Channel Maintenance Flow Needs: The Cache la Poudre River. Paper 26012 in, Webb JA, Costelloe JF, Casas-Mulet R, Lyon JP, Stewardson MJ (eds.) Proceedings of the 11th International Symposium on Ecohydraulics. Melbourne, Australia, 7-12 February 2016. The University of Melbourne.

USGS. 2016. National Water Information System. Data downloaded from water data pages for Colorado and Montana. 
Slide 1. Title slide. Present the title page and proceed.

\title{
Quantitative assessment of sediment transport and channel maintenance capacity of rivers
}

\author{
Robert T Milhous \\ Torries Peak Analysis \\ Fort Collins, Colorado
}

Slide 2. Discuss the objective of the paper.

\section{Objective of Presentation}

\section{The objective is to introduce a quantitative tool that can assist in making water management decisions where channel maintenance is important.}

Slide 3. Continue discussion of the objective of the paper

\section{Second Objective of Presentation}

It is common knowledge that the channel of a river is maintained if:

1) when the streamflows exceed the mean annual peak discharge or

2) when the streamflows exceed an effective discharge.

An alternative will now be presented. This alternative considers;

1) intervals between events and

2) duration of events that have the capacity to maintain the channel

Slide 4 In previous work (Milhous, 2016) the discharge required to remove vegetation from bars in the

Poudre River was estimated to be $147 \mathrm{~m}^{3} / \mathrm{s}(5191.26 \mathrm{cfs})$. The value of $147 \mathrm{~m}^{3} / \mathrm{s}$ is assumed to be the critical value for channel maintenance considering vegetation on bars. The equation used for the computation of the CMCI is CMCI $=(\mathrm{QD} * * 0.500$ - 5191.260**0.500/( $1000.000 * *$ 0.500). Measured daily discharges were used in the computations. The CMCI required to remove the vegetation for each water year is shown on the this slide. The objective the original analysis was to investigate the impacts of reservoirs on the North Fork of the Poudre River on the ability of the river to keep river bars free of vegetation. In 1910 North Poudre Irrigation Company completed Halligan Reservoir with a capacity of 6,400 acre-feet. In 1943, Greeley completed 
construction of Milton Seaman Dam which impounded a reservoir of 5,000 acre-feet. The annual peak and daily discharges in the Poudre River measured at the mouth of Poudre Canyon are presented in this slide. The zero values shown on the figure are where the daily discharges were less than $5191.26 \mathrm{cfs}$ (therefore CMCI is zero) and the peak discharge is larger than $5191.26 \mathrm{cfs}$. In 1904 a major rain storm occurred on the North Fork with a peak discharge at the gage in the order of $21000 \mathrm{cfs}$. The CMCI would almost certainly have been a relatively large value. The situation based on the 1944 thru 2016 (peak) or 2015 (others) is in the table below.

\begin{tabular}{|c|c|c|c|c|c|}
\hline Water year & $\begin{array}{c}\text { Annual peak Q, } \\
\text { cfs }\end{array}$ & $\begin{array}{c}\text { Return period, } \\
\text { years }\end{array}$ & Annual Q, cfs & STCI(sand) & $\begin{array}{c}\text { CMCI } \\
\text { (vegetation) }\end{array}$ \\
\hline 2013 & 9730 & 142.86 & 342.87 & 151.83 & 0.47 \\
\hline 1976 & 7340 & 47.62 & 216.72 & 65.48 & 0.00 \\
\hline 1983 & 6590 & 29.41 & 897.93 & 632.00 & 0.81 \\
\hline
\end{tabular}

The annual unregulated discharge in 1983 has a return of at least 200 years. The peak discharge in 1976 is the second in the 72 years from 1944 to 2016 and 1983 is the third (2013 is the first).

\section{Cache la Poudre River}

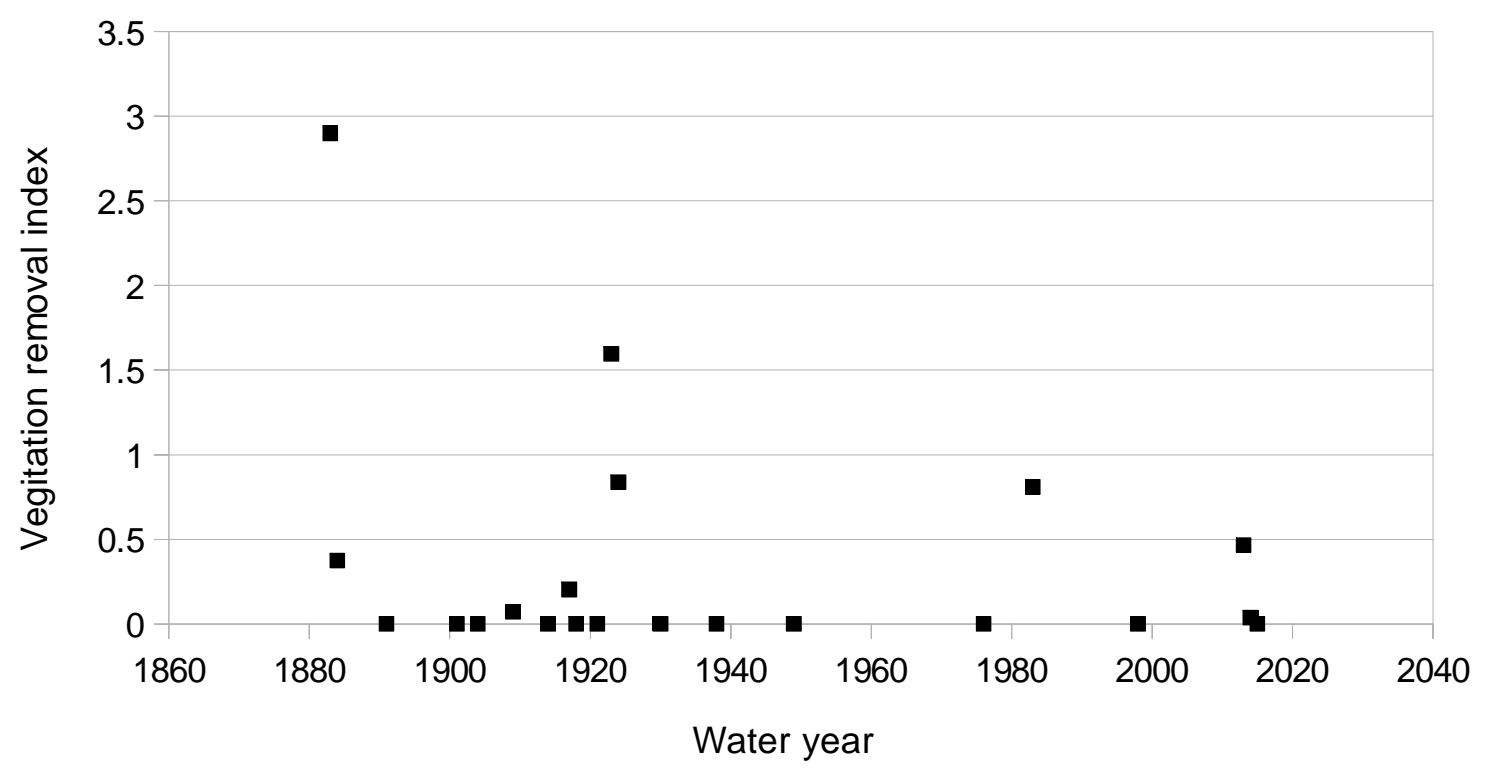

Slide 5. Suspended sediment concentrations as related to discharge in the Clarks Fork Yellowstone River near Belfry MT. One of the measurements was made in 1965, 4 in 1971, and 6 in 1984. The orange points are for streamflows near the peak discharge for the year. The blue points are for other periods. The equation for a trend line fit to the blue points is $\mathrm{SC}=8.51 \mathrm{Q} * * 1.08(\mathrm{R} 2=0.38)$, for the yellow points $\mathrm{SC}=6.73 \mathrm{Q}^{* *} 0.78(\mathrm{R} 2=0.90)$ where the discharge is in $\mathrm{m}^{3} / \mathrm{s}$. For a line fit to all the data $\mathrm{SC}=1.593 \mathrm{Q} * * 0.73(\mathrm{R} 2=0.33)$ where the discharge is in cms. The assumption made is that fines are flushed from the system as the streamflows increase in the spring and not available for transport at the higher flows. The peak streamflows for each year with suspended sediment 
concentration data are in the following table. The discharges in the equations is cubic feet per second, cfs.

\begin{tabular}{|c|c|c|}
\hline Water year & Peak discharge, cfs & Date of peak \\
\hline 1965 & 8600 & 26 JUNE \\
\hline 1971 & 10200 & 23 JUNE \\
\hline 1984 & 6750 & 30 JUNE \\
\hline Q2 & 7765 & \\
\hline
\end{tabular}

\section{Clarks Fork Yellowstone River near Belfry MT}

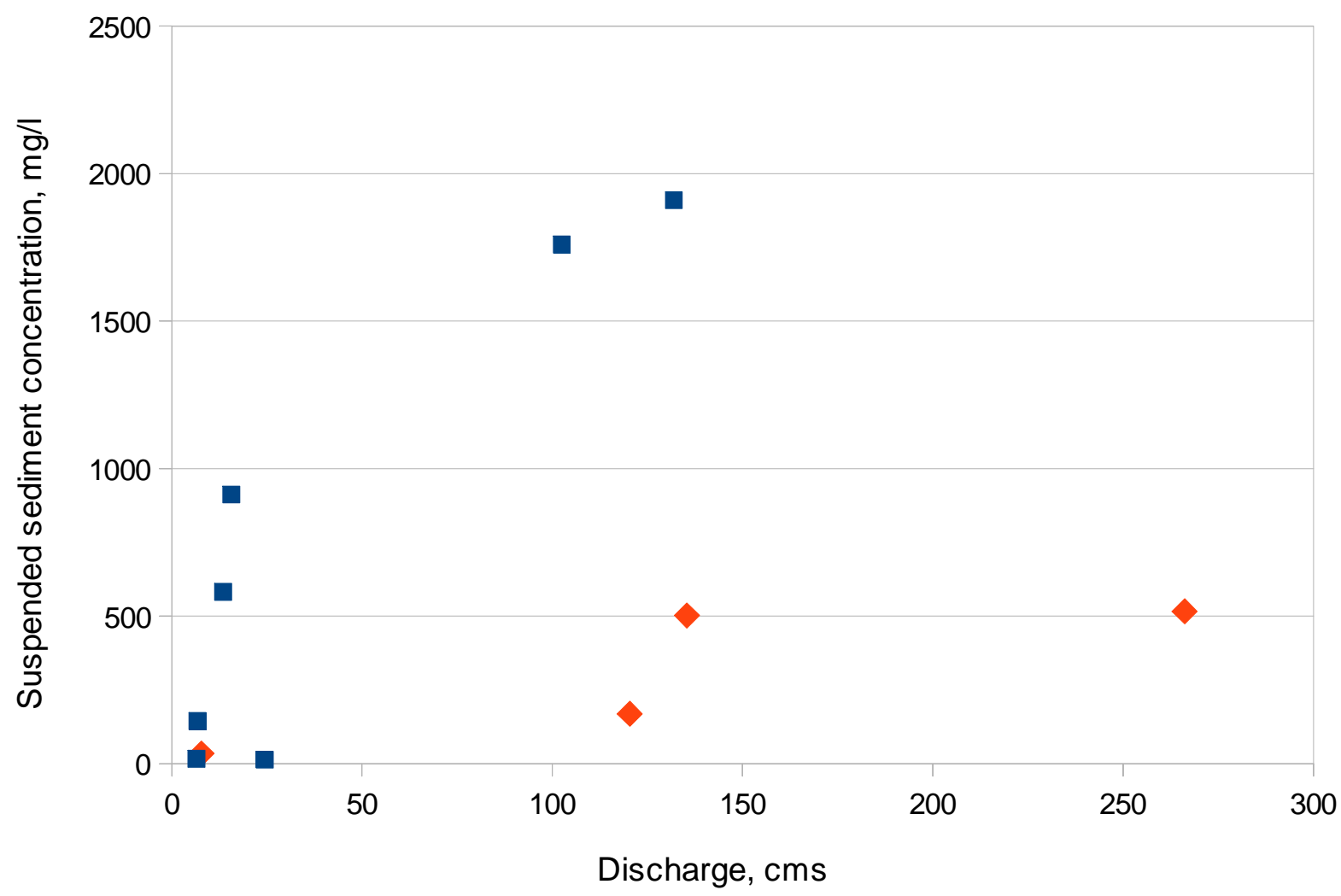

Slide 6. Suspended sediment load as related to discharge in the Clarks Fork Yellowstone River near Belfry MT. The trend line is fit to all the data and has the equation $\mathrm{SL}=0.0033 \mathrm{Q}^{* * 1.73}$

$(\mathrm{R} 2=0.74)$. The equation fit to the all the concentration data is $\mathrm{SC}=1.25 \mathrm{Q} * * 0.73\left(\mathrm{R}^{2}=0.33\right)$. Looks good - except it is misleading. Look at the concentration versus discharge data without transformation. Effective discharge calculated with the relation on this diagram would be a joke. The discharges in the equations are in traditional English units. 


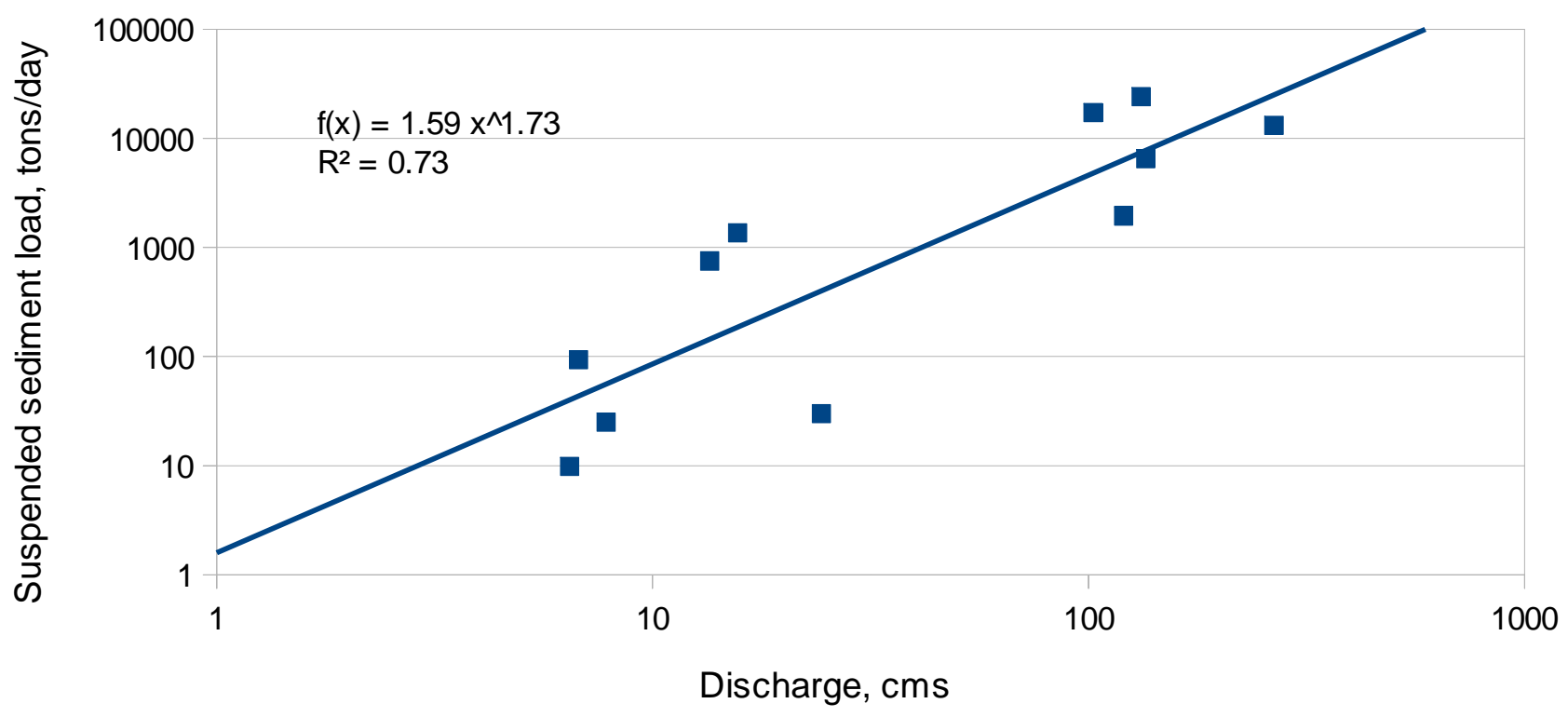

Slide 7. Present the sediment transport capacity index (STCI) and discuss the logic. The equation for sediment load (SL) assumes the concentration is related to the difference between the discharge and a discharge, Qcrt, required ti initiate movement. The equation for CMCI assumes shear stress is important and that the shear stress is related to the discharge to some power. The effective channel maintenance is assumed to be that portion of the shear stress to some power $\left(\mathrm{Q}^{* *} \mathrm{~b}\right)$ that is above a minimum value (Qcrt**b). The shear stress is related to the depth. The hydraulic geometry equations give depth is related to depth to some power, $i$. If the channel maintenance capacity is related to the shear stress to some power, $\mathrm{j}$; the power term, $\mathrm{b}$, in the CMCI equation is $b=i * j$.

\section{Sediment Transport Capacity Index}

$$
\begin{gathered}
\text { Basic equation } \\
\mathrm{SL}=\Sigma\left[\mathbf{a}(\mathbf{Q}-\mathbf{Q c r t})^{\mathbf{b}}\right]^{*} \mathbf{Q}
\end{gathered}
$$

Divide by the load at a reference discharge

$$
\text { STCI }=\Sigma\left\{\left[\left(Q_{-Q c r t}\right)^{b}\right]^{*} Q\right\} /\left\{\left({\text { Qref-Qcrt })^{b}}^{b}{ }^{*} \text { Qref }\right\}\right.
$$

The equation used for a channel maintenance capacity index

$$
\mathrm{CMCI}=\Sigma\left[(\mathbf{Q})^{\mathrm{b}}-\left(\mathbf{Q c r t}^{\mathrm{b}}\right] /\left[\left(\mathbf{Q r e f}^{\mathrm{b}}\right]\right.\right.
$$


Slide 8. Formulation of the channel maintenance capacity index. The basic assumption is that the shear stress in excess of some critical shear stress is the shear stress that maintain the channelthis is an 'effective' shear stress.

$$
\begin{aligned}
& \text { Channel Maintenance Capacity Index } \\
& \mathrm{cm}=\mathrm{f}\left(\mathrm{T}-\mathrm{T}_{\mathrm{crt}}\right) \text { effective shear stress } \\
& \tau=\gamma \mathrm{RS} \quad \text { appx }=\gamma \mathrm{dS} \\
& \mathrm{d}=\mathrm{a} \mathrm{Q}^{\mathrm{b}} \text { hydraulic geometry relation } \\
& \tau=\gamma\left(\mathrm{aQ}^{\mathrm{b}}\right) \mathrm{S} \\
& \mathrm{CMCl}=\Sigma\left[\left(Q^{b}-Q_{c r t}^{b}\right) / Q_{r e f}^{b}\right]
\end{aligned}
$$

Slide 9. Suspended sediment concentrations as related to discharge in the Clarks Fork Yellowstone River near Belfry MT. One of the measurements was made in 1965, 4 in 1971, and 6 in 1984. The orange points are for streamflows near the peak discharge for the year. The blue points are for other periods. The equation for the upper limiting line (90\% quantile) fit to all the data is $\mathrm{SC}=$ $100.1 *$ ( Discharge ) ** 0.3499. The assumption made is that the capacity of the river to transport fines and sand is represented by the upper limiting line.

\section{Clarks Fork Yellowstone River near Belfry MT}

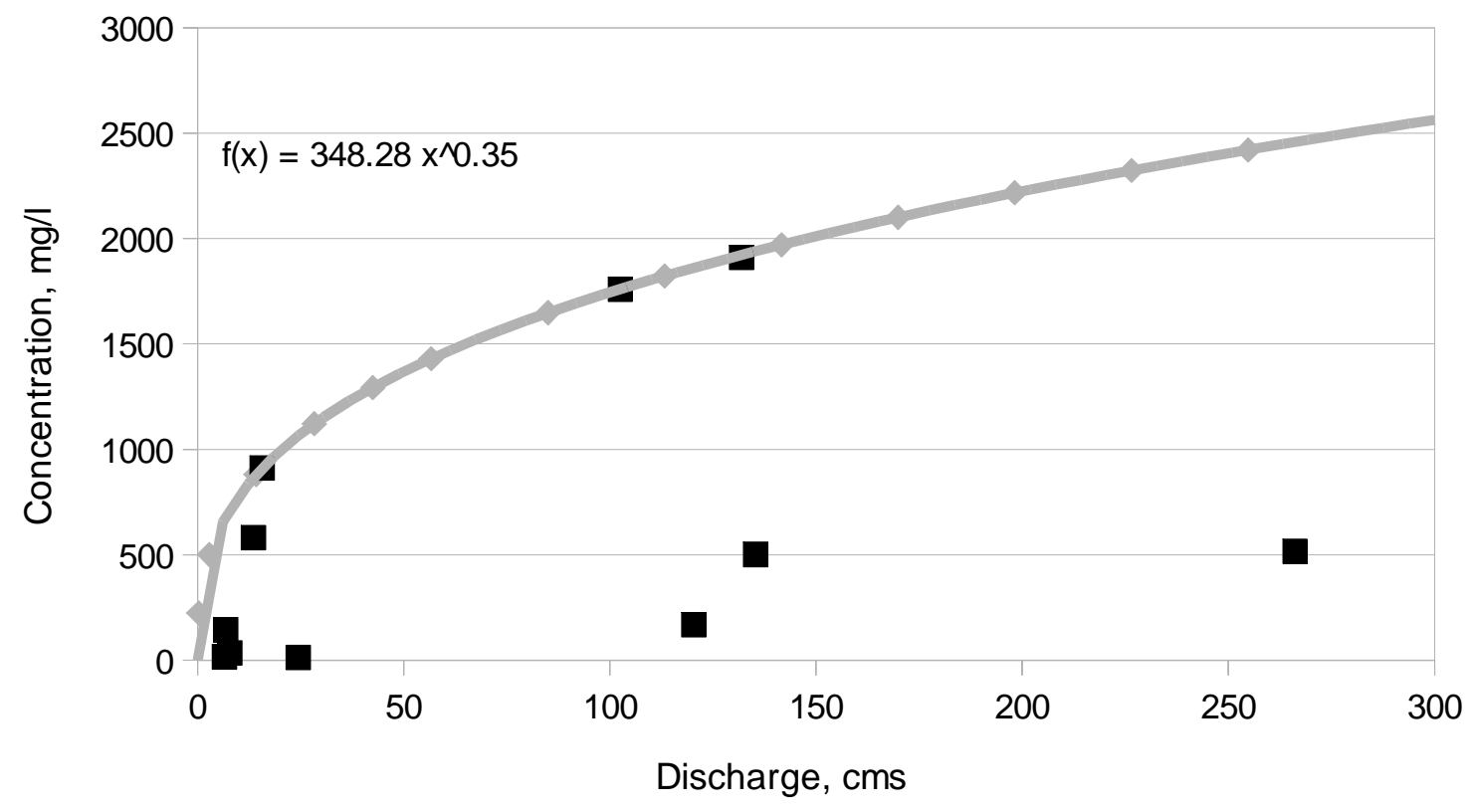

Slide 10. Daily streamflows have been measured for the Clark's Fork Yellowstone for water years 1922 -2015 . The equation for the daily sediment transport capacity index for the capacity of the river to transport sand and fine is stci $=(\mathrm{QD} / 1000.0)^{* *} 1.350$. The annual STCI is the sum of the daily stci. 


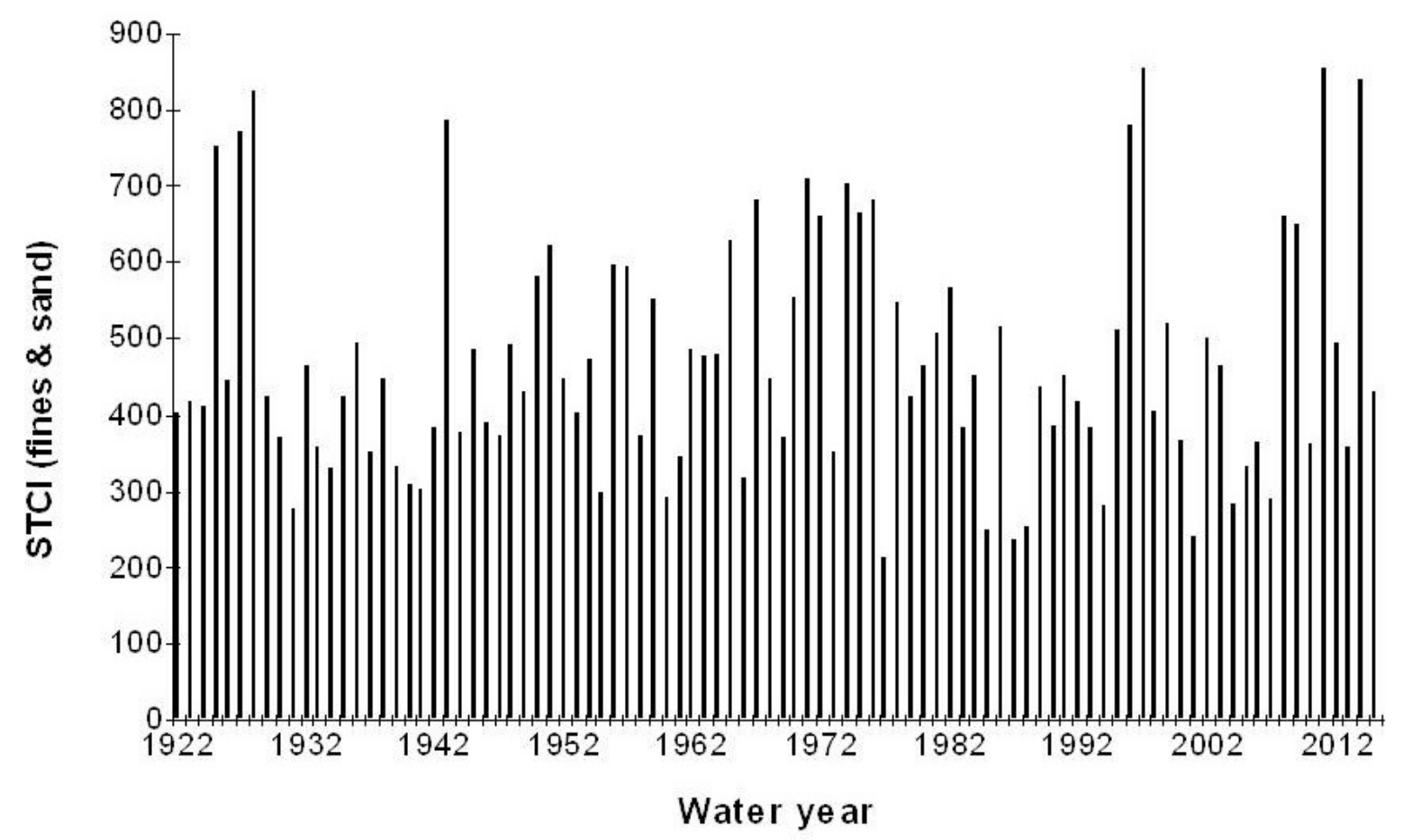

Slide 11 The relation between discharge and suspended sediment concentrations in the Cache la Poudre River in Colorado is presented in this slide. The LAD relation between the discharge and concentration is [Concentration $=.365 *$ ( Discharge $* * 0.5056$ )] compared to the least squares relation of [Concentration $=0.8487 *$ (discharge $* * 0.6154)$ ] when the units are in cfs. For metric units, cms, the alpha coefficient is 2.71 for the LS solution. The limiting relation is [Concentration $=.8487 *($ Discharge $* * 0.6154)]$ when the discharge is in cfs.. All the data available was used in the analysis. 


\section{Cache la Poudre River}

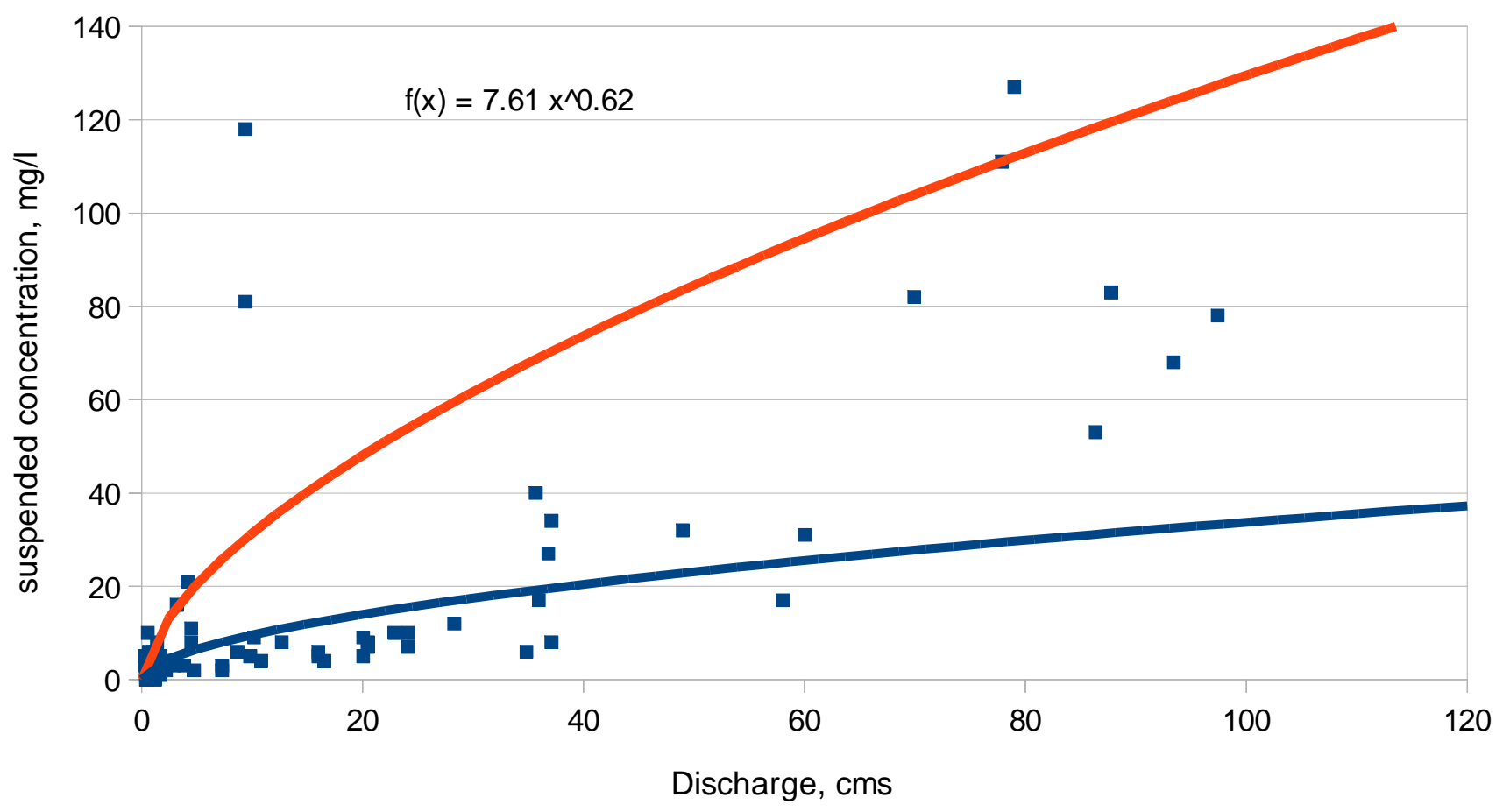

Slide 12 The annual value of the STCI required to move sand and fines is presented in this slide. The equation for the daily stci is [STCI $\left.=(\mathrm{QD} / 1000.000)^{* *} 1.615\right]$ where QD is the daily discharge in cubic feet/ second (cfs) $\{1000 \mathrm{cfs}=28.3 \mathrm{cms}\}$. The average values are for periods defined by the constructions of reservoirs on the North Fork of the Poudre River; Hallgen was completed in 2010 and Seamon in 1943. 1904 is missing and was a year with a major flood coming from the North Fork.

\section{Cache la Poudre River}

\begin{tabular}{|c|c|c|c|c|}
\hline Period & Number of years & Qmean, cfs & $\begin{array}{c}\text { STCI(sand \& } \\
\text { fines) }\end{array}$ & Peak day, cfs \\
\hline $1884-1909$ & 25 & 480.64 & 208.57 & 3269.20 \\
\hline $1911-1942$ & 32 & 397.34 & 176.15 & 3154.38 \\
\hline $944-2015$ & 72 & 325.51 & 132.19 & 2605.26 \\
\hline
\end{tabular}

Slide 13 The average values are for periods defined by the constructions of reservoirs on the North Fork of the Poudre River; Hallgen completed in 2010 and Seamon in 1943. 1904 is missing and was a year with a major flood coming from the North Fork. An annual peak of $18000 \mathrm{cfs}$ was included in the 1883-1909 period for the annual peak average. 


\section{Cache la Poudre River}

\begin{tabular}{|c|c|c|c|c|c|}
\hline Period & $\begin{array}{c}\text { Number of } \\
\text { years }\end{array}$ & $\begin{array}{c}\text { Annual } \\
\text { discharge } \\
\mathbf{m}^{3} / \mathrm{s}\end{array}$ & $\begin{array}{c}\text { Sediment } \\
\text { transport } \\
\text { capacity index } \\
\text { (sand \& fines) }\end{array}$ & $\begin{array}{c}\text { Maximum } \\
\text { daily } \\
\text { discharge, } \\
\mathbf{m}^{3} / \mathrm{s}\end{array}$ & $\begin{array}{c}\text { Annual peak } \\
\text { discharge, } \\
\mathbf{m}^{3} / \mathbf{s}\end{array}$ \\
\hline $1884-1909$ & 25 & 13.61 & 208.31 & 92.57 & 148.52 \\
\hline $1911-1942$ & 32 & 11.25 & 176.15 & 89.32 & 112.81 \\
\hline $1944-2015$ & 72 & 9.22 & 132.19 & 73.77 & $\mathbf{8 9 . 4 8}$ \\
\hline
\end{tabular}

Slide 14 Start of Poudre Case Study. In this section SDEIS refers to Supplemental Draft Environmental Impact Statement, NISP Northern Integrated Supply Project and district to the Northern Colorado Water Management District. The streamflow data used in the following slides is for the Cache la Poudre River at Fort Collins (USGS gage number 06752060). The gage is also called the Lincoln Street gage.

\section{Cache la Poudre Case Study}

Slide 15 Annual index to the capacity of the Cache la Poudre River to transport fine sediment. The index was calculated using the daily streamflows at the Lincoln Street gage Run, 1 was calculated using streamflows for the 'No Action Alternative' and Run 3a is the 'District's Preferred Alternative'

This comment is about the ability of the Poudre River to move fine sediment. Fine sediment is sediment $2 \mathrm{~mm}$ or smaller (sand is $0.064-2 \mathrm{~mm}$, fines $<0.064 \mathrm{~mm}$ ). The equation used to calculate an index to the capacity of the river to transport fine sediment is:

$$
\mathrm{FSTCI}=\Sigma[\mathrm{QD}(\mathrm{I}) / \mathrm{Qref}]^{* *} \beta
$$

where FSTCI is the index to capacity of the river to transport fine sediment, $\mathrm{Q}_{\mathrm{ref}}$ is a reference discharge, and $\beta$ is a power term that relates the discharge to the suspended sediment load using a power relation often used in suspended sediment load analysis. The Fine Sediment Transport Capacity Index (FSTCI) calculated using the measured daily discharge for each year is shown in this slide along with the FSTCI for the 'No Action Alternative' (Run 1) and the 'District's Preferred Alternative' (Run3a). Percent change in the index between the measured streamflows and District preferred alternative; and difference between the no action alternative use in the SDEIS; and the District's preferred alternative' are shown in Slide 16. Slide 17 is a duration plot of the annual values in Slide 16 that shows the no action alternative may underestimate the impacts that are likely to occur (closer to the measured).. 


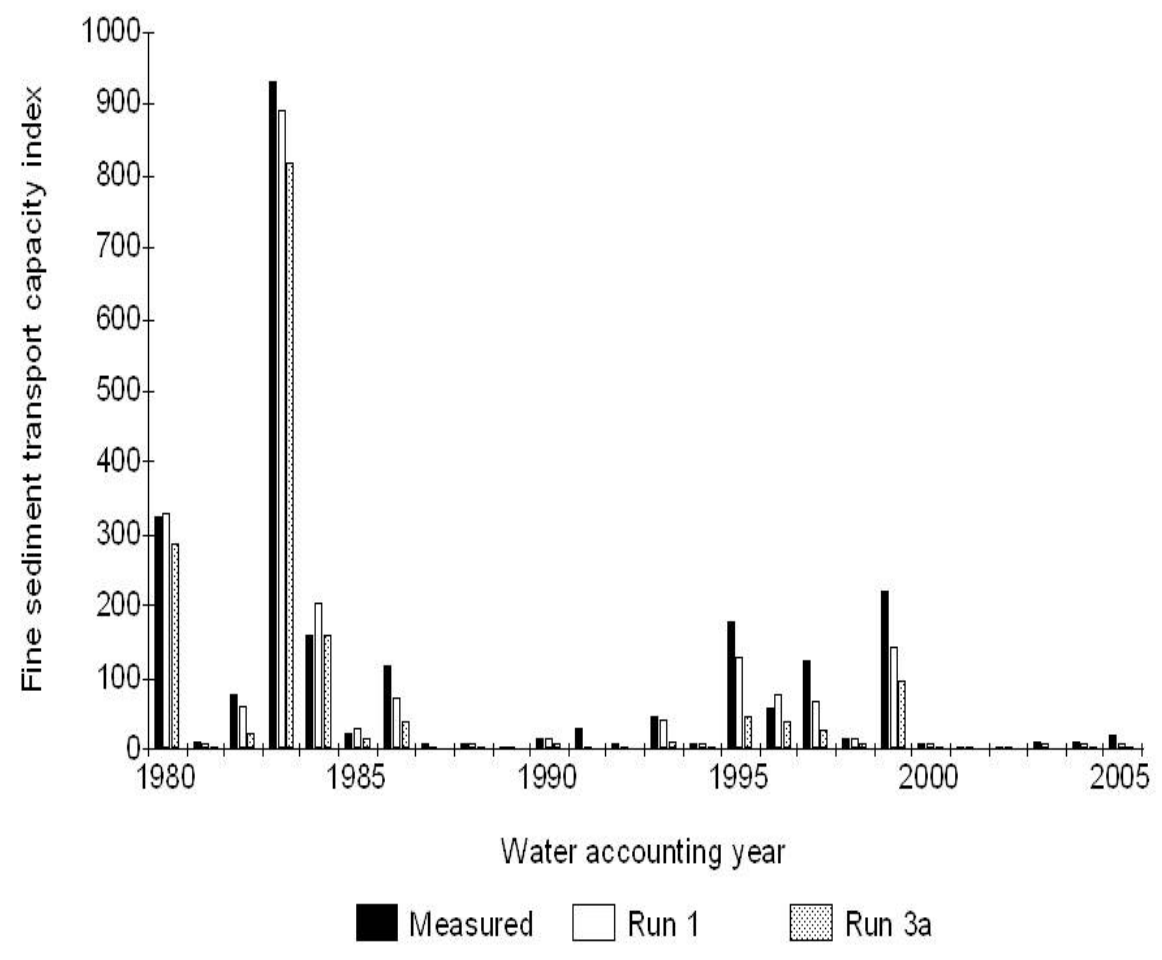

Slide 16 Percent change in annual index to the capacity of the Poudre River at the Lincoln Street gage to transport fine sediment and sand calculated as the difference between the measured annual discharge minus the 'District's Preferred Alternative' (Measured) and the difference between the 'No Action Alternative' and the 'District's Preferred Alternative' (Run 1).

There is a significant impact of the NISP project on the capacity of the Poudre River to transport fine sediment and sand as is illustrated by this slide. The biggest percent change is when the streamflows are the lowest which might also be the times when the streamflow is needed to move the fine sediment through the river without increasing the fines and sand in the substrate surface. An increase of fines and sand in the substrate surface would not be good for the aquatic habitat. Because of the reduction in capacity there is a good chance the gravels would be needed to be 'flushed' of fine sediment more often and with larger flushing flows than is the case with the present streamflow conditions 


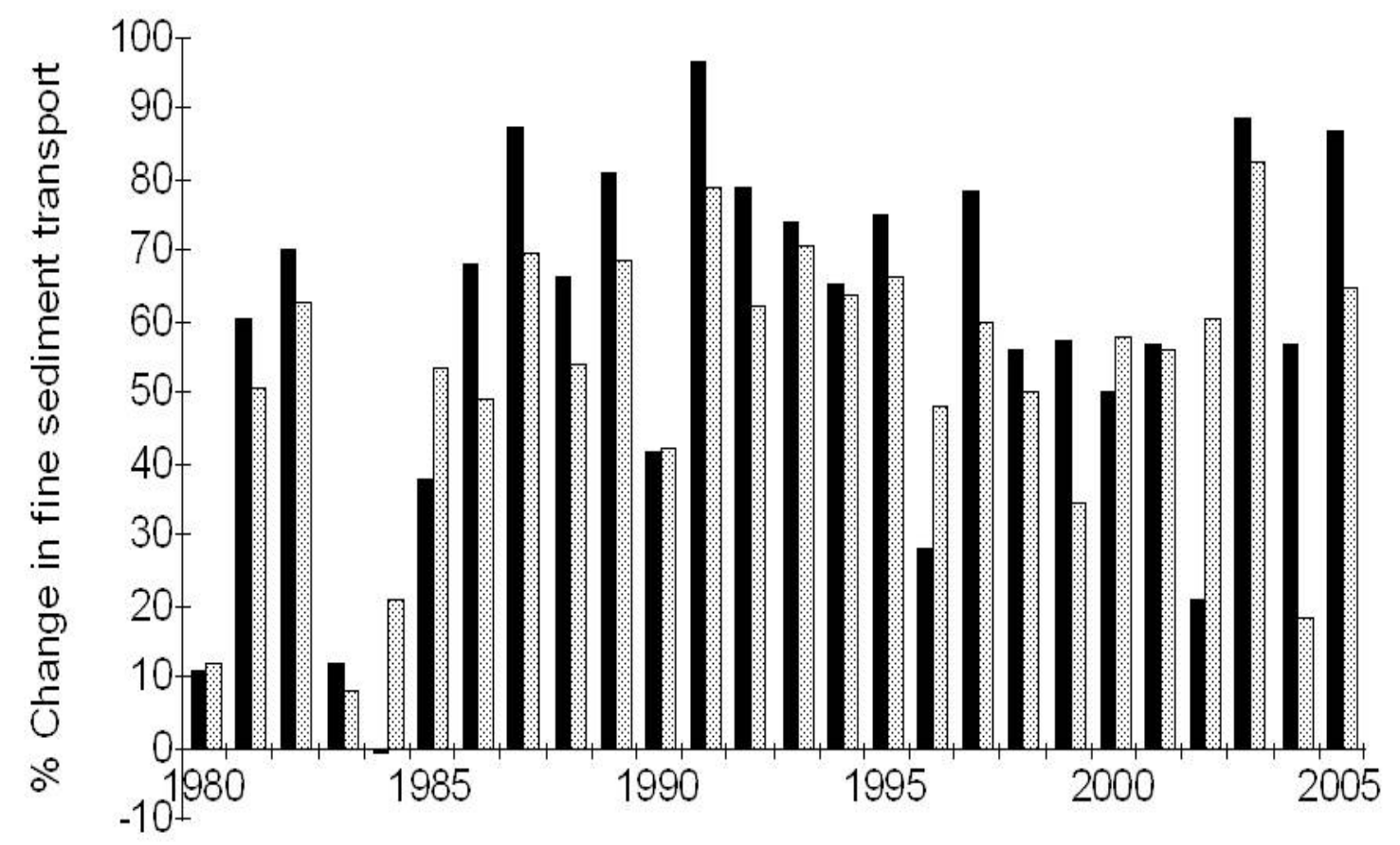

Water accounting year

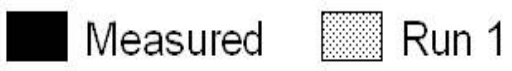

Slide 17 .Duration relations for the percent change in annual index to the capacity of the Poudre River to transport fine sediment and sand calculated as the difference between the measured annual discharge minus the 'District's Preferred Alternative' (Measured) and the difference between the 'No Action Alternative' and the 'District's Preferred Alternative' (Run 1). 


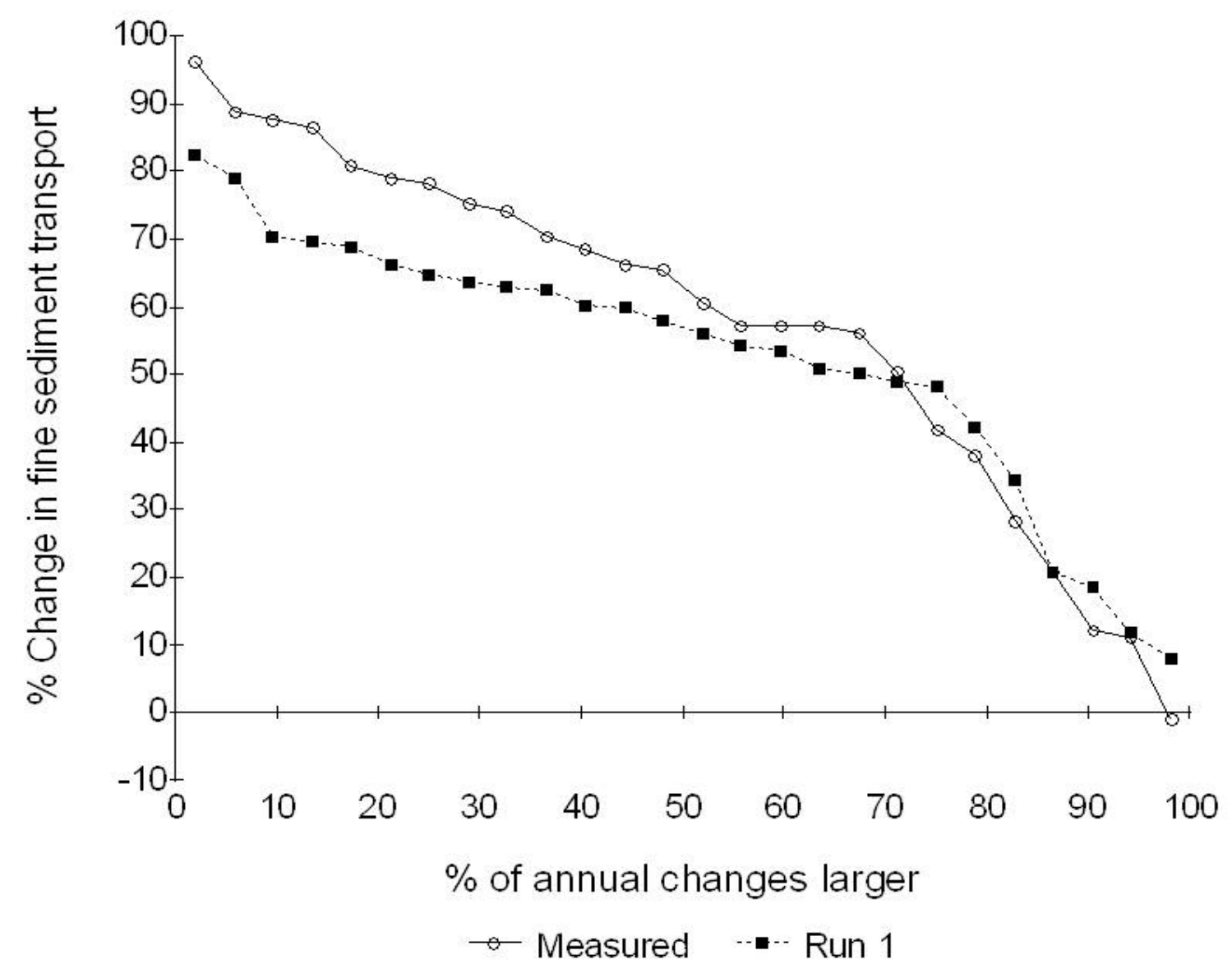

Slide 18 Annual index to the channel maintenance capacity index of the Poudre River to maintain its channel. The index was calculated using the daily streamflows at the Lincoln Street gage, Run 1 was calculated using streamflows for the 'No Action Alternative' and Run 3a is the 'District's Preferred Alternative'.

My next comment was about the impact of the NISP project on the channel maintenance capacity of the river. An index to the channel maintenance capacity of the riverthat was used to look at the changes in the capacity caused by the NISP is:

$$
\mathrm{CMCl}=\Sigma\left[\left(\mathrm{Qd}(\mathrm{i})^{\beta}-\mathrm{Qcrt}^{\beta}\right) / \mathrm{Qref}^{\beta}\right]
$$

where $\mathrm{CMCI}$ is the channel maintenance capacity index, $\mathrm{Qd}(\mathrm{i})$ is the daily discharge, $\mathrm{Q}_{\mathrm{crt}}$ is a critical discharge, Qref is a reference discharge, and $\beta$ is power coefficient based on the relation between the discharge and sediment load. The reference discharge used was $1000 \mathrm{cfs}$, the power term used was 2.0 and the $\mathrm{Q}_{\text {crt }}$ used was $2000 \mathrm{cfs}$ based on information in the SDEIS. The summation is over all daily discharges where the daily discharge exceeds the critical discharge (2000 cfs). The $2000 \mathrm{cfs}$ critical discharge was based on information in Anderson Consulting Engineers, Inc., 2013. 


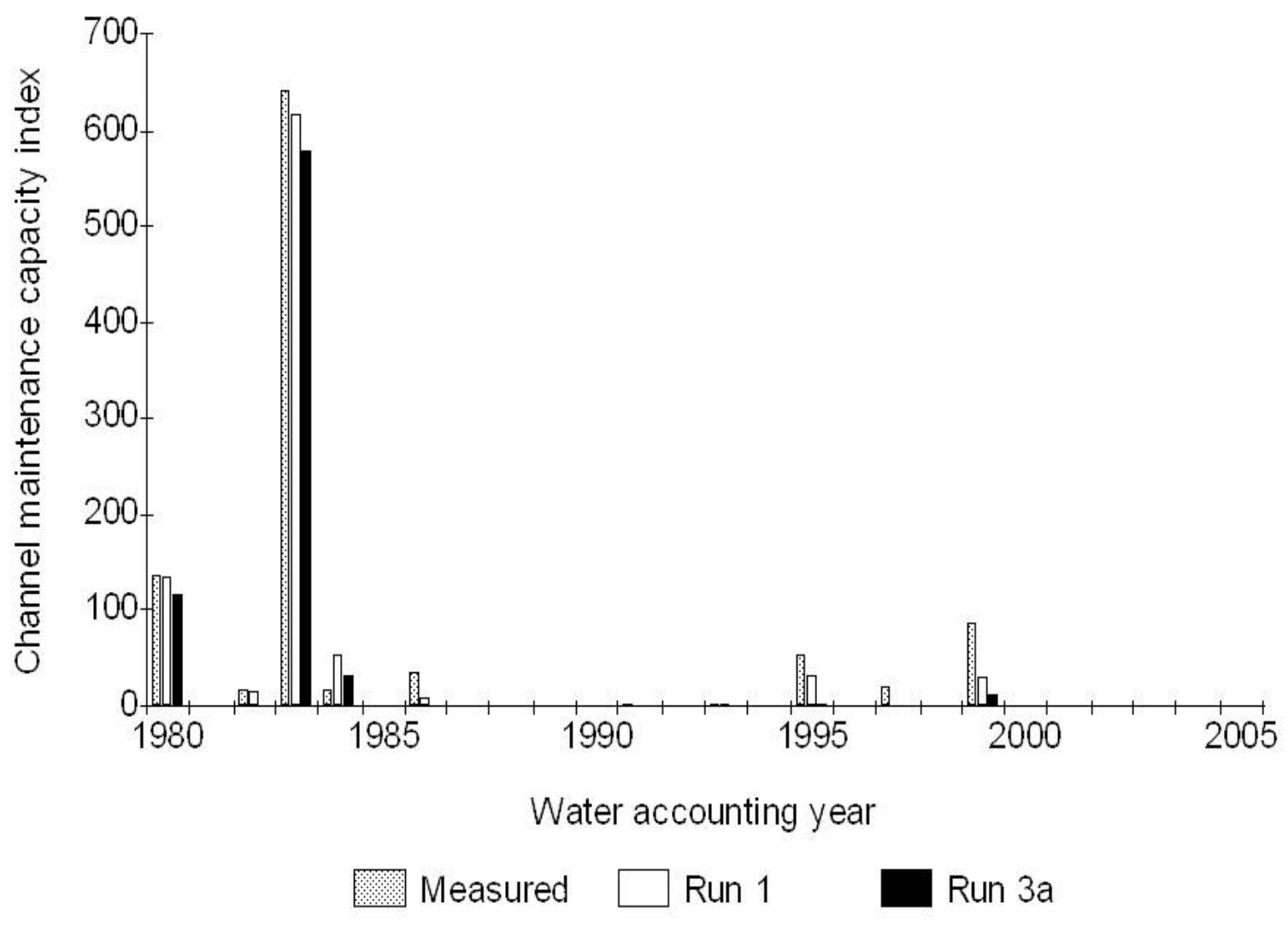

Slide 19 Percent change in the annual channel maintenance capacity index to the capacity of the Poudre River to maintain its channel. The index was calculated using the measured daily streamflows at the Lincoln Street gage, Run 1 was calculated using streamflows for the 'No Action Alternative' and Run 3a is the 'District's Preferred Alternative'.

The calculated channel maintenance capacity index is presented in Slide 18 and the percent change in the index in this slide. A change of $100 \%$ indicated all of the channel maintenance capacity is eliminated by NISP. The figure demonstrates that the intervals between streamflows that can maintain the channel will be increased by the NISP. The change in intervals between channel maintenance events was not well investigated in the SDEIS. The change in length of intervals between channel maintenance events could have a significant impact on the channel of the Cache la Poudre River. 


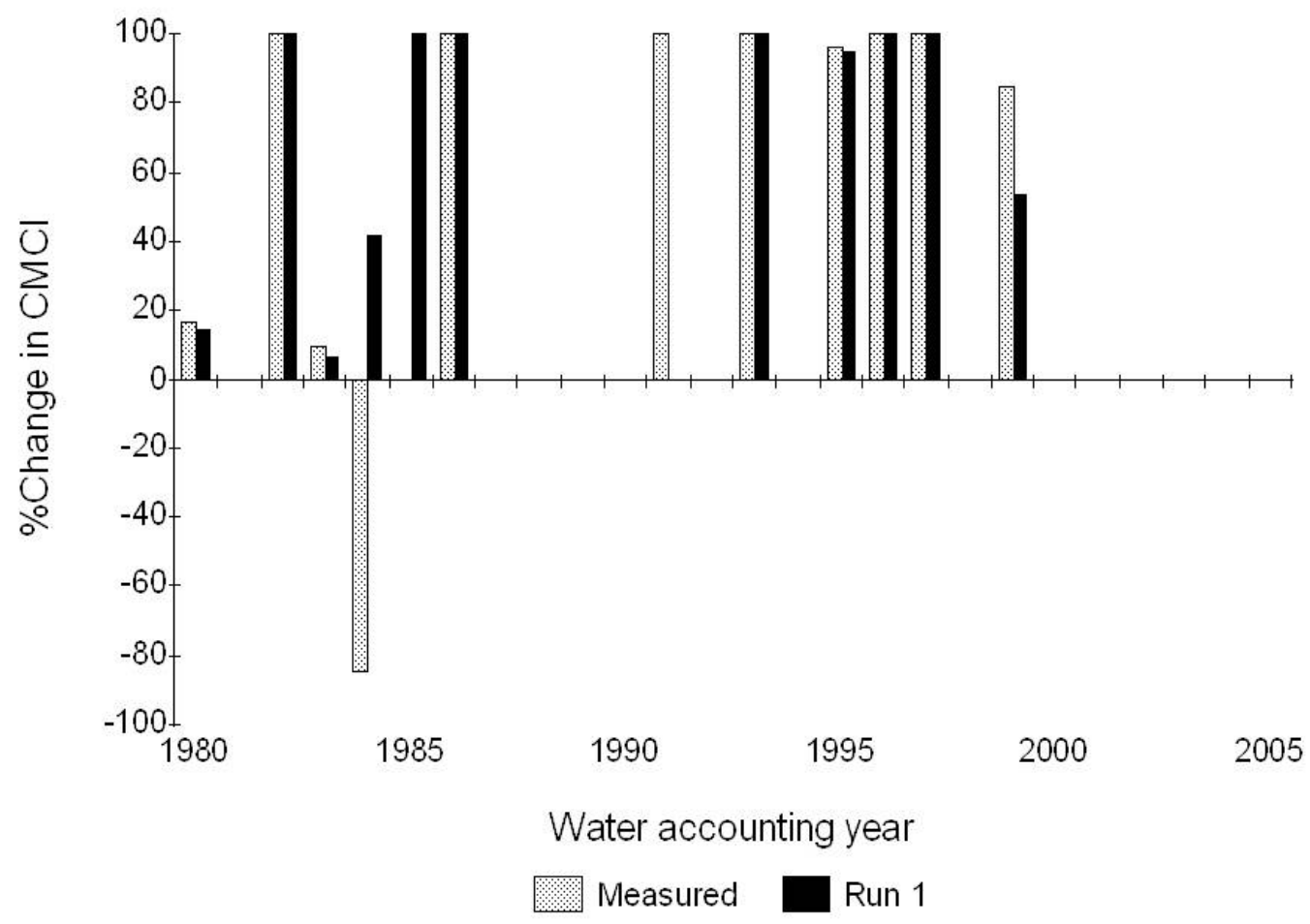

Slide 20. Channel maintenance capacity index for 1950-2014 calculated using streamflows measured at the canyon mouth. My last comment is about the time period used in the SDEIS (Water accounting years 1980-2015). On Slides 15 and 18 the year 1983 stands out as having significantly larges values of sediment transport capacity than the other years. The question is: how representative is 1983 of the streamflows and the various calculated indices? On this slide is the calculated channel maintenance capacity index for 1950 - 2014 at the canyon mouth. The year 1983 would appear not to be representative. Data on estimated native flows in the river are available. Analysis of the data shows the return period of the 1983 annual streamflows is between 100 and 125 years. There was a major peak discharge in 1976 with a short duration. The calculated CMCI for the year,1976, is very small. More work needs to be done to understand how to link duration and magnitude. 


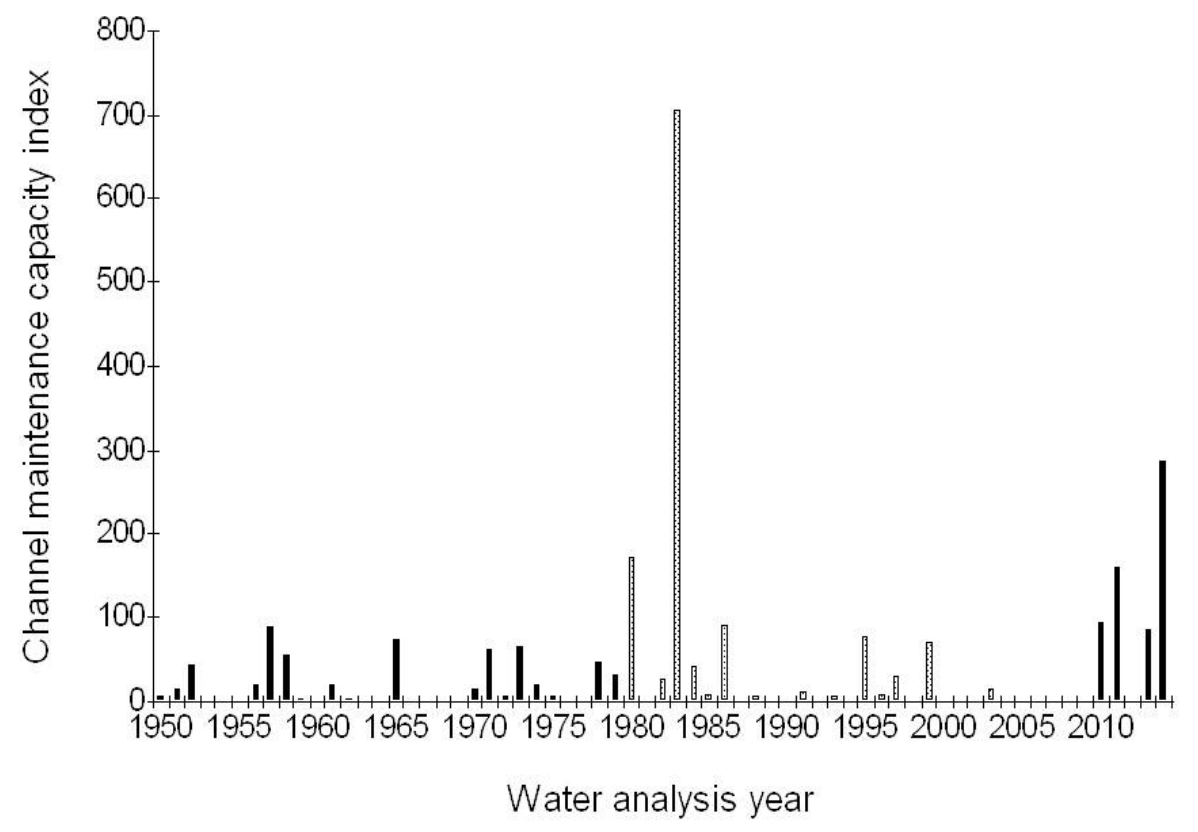

Slide 21. End slide. Picture of the Platte River near Gibbon, Nebraska at sunrise.

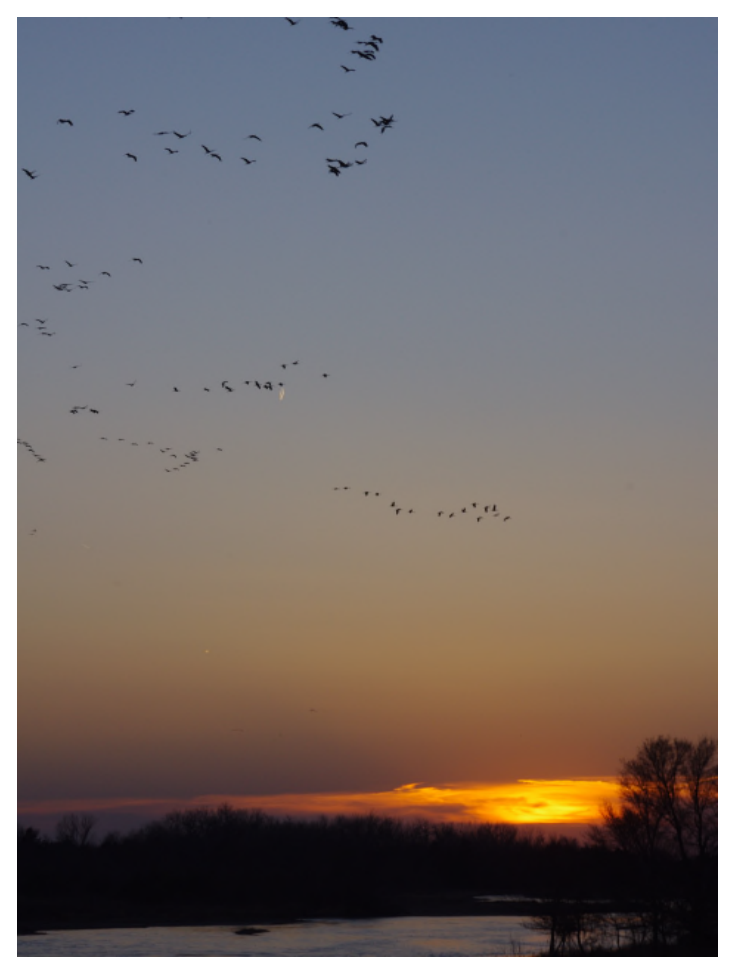

